\title{
Est-6 in Drosophila melanogaster: effects of genetic composition, temperature and oviposition period on fitness in laboratory populations polymorphic for rare alleles
}

\author{
Loredana Nigro*, \\ Rodolfo Costa*, \\ Suresh D. Jayakar† and \\ Laura Zonta†
}

\author{
* Dipartimento di Biologia, Sezione di Genetica, \\ Università di Padova, Vía Loredan 10, 35101 Padova, \\ Italy. \\ † Dipartimento di Genetica e Microbiologia "A. \\ Buzzati-Traverso", Università di Pavia, Via S. Epifanio \\ 14, 27100 Pavia, Italy.
}

The Esterase-6 locus in Drosophila melanogaster is known to be involved both in the metabolism of esters and in sperm use and remating of females. Several studies have also produced evidence for selective differences between the allozymic variants at this locus. In this paper we have studied the selection differences when two rare alleles (Est-6 VS and $E s t-6$ VF) are competing on the one hand, and when a common allele (Est-6 F) is in competition against the rare allele Est-6 VF on the other. Isogenic lines with homogeneous background were used.

In general in the first experiment we found a heterozygous advantage and in the latter strong selection against the rare allele. There was no evidence for any frequency dependent selection. The selective differences were also studied with respect to three different input gene frequencies, three temperatures and in two different periods of oviposition. All the factors were found to influence both the total number of flies emerging and their genotypic composition. There was also interaction between the selective effects of these factors.

\section{INTRODUCTION}

In the last few years the Est-6 locus in Drosophila melanogaster has become particularly interesting in the light of new findings relating to one of the physiological functions of the enzyme Esterase- 6 as well as to the geographical pattern of variation of the polymorphism at this locus.

Esterase-6 (E.C. 1.1.1., Wright, 1963) seems to be involved in the mechanism of reproduction affecting both storage and use of sperm in females (Richmond et al., 1980; Richmond and Senior, 1981; Gilbert, 1981; Gilbert et al., 1981). The involvement of Esterase- 6 in sperm use and daily productivity in terms of progeny is known to be affected by temperature (Gilbert and Richmond, 1982). Moreover Esterase-6 together with a male specific lipid (cis-vaccenylacetate), a component of the seminal fluid, seems to constitute a substrateenzyme system that is involved in the pheromonal regulation of the timing of remating in females (Mane et al., 1983).

Esterase- 6 also appears to be involved in the metabolism of esters naturally occurring in food, as suggested by a number of results (Danford and Beardmore, 1979; 1980; Zera et al., 1983).

A large scale geographical survey on the distribution of Est-6 allele frequencies (Oakeshott et al., 1981; Anderson and Oakeshott, 1984) shows the existence of a recurrent latitudinal cline in three continents both in Drosophila melanogaster and in the homologous gene-enzyme system in the sibling species Drosophila simulans. Such a pattern seems difficult to explain as being due solely to random processes.

Two common and four rare electrophoretic variants have been described in natural populations. Isoelectrophoretic alleles relative to heat stability, substrate specificity and activity (see references in Costa et al., 1982) have also been found. 
Moreover functional differences among allozymes have been reported (Danford and Beardmore, 1979; Costa et al., 1983; Mane et al., 1983). Selection in egg-to-adult viability has been observed in laboratory populations, apparently in relation to the polymorphism at the Est-6 locus, and selective intensity is significantly modified by temperature, density and composition of the medium (Wright, 1963; Kojima and Yarbrough, 1967; Morgan, 1976; Birley and Beardmore, 1977; Costa and Beardmore, 1980). In a few cases however, experiments cast doubt on the hypothesis of adaptive significance of the Est-6 polymorphism (Dolan and Robertson, 1975; Clegg et al., 1976; 1978).

Except in one case (Costa and Beardmore, 1980), the laboratory studies on the dynamics of this polymorphism known to us have examined the Est-6 alleles common in the wild (Est-6 Slow and Est-6 Fast).

Here we present the results in egg-to-adult viability obtained with laboratory populations polymorphic at the Est-6 locus in which a rare allele (Est-6 Very Fast) was tested at different frequencies against a common allele (Est-6 Fast) or against another rare one (Est-6 Very Slow). The definition of "rare" is based on the frequency normally found in the wild (Danieli and Costa, 1977).

In experiments of this kind, there is always the possibility that any effect found might be caused by heterogeneity in the genetic background or by linkage disequilibrium. Our lines were prepared, as described in the next section, so as to strongly reduce the intensity of such interactions.

\section{MATERIALS AND METHODS}

\section{(i) Lines used}

The lines derive from a large natural population sampled in the Venetia region (N. Italy). Five isogenic homozygous lines per genotype were first extracted. Then, in order to randomise the genome and increase the homogeneity of the genetic background, the homozygous lines (Est-6 VS/Est-6 VS, Est-6 F/Est-6 F, Est-6 VF/Est-6 VF) were intercrossed (Est-6 VS/Est-6 VS vs Est-6 VF/Est-6 VF and Est-6 F/Est-6 F vs Est-6 VF/Est-6 VF) for a period of 4 years of continuous culture and lines homozygous for the three alleles were then extracted from these populations. The population sizes during this process were maintained at a level (2000-3000 individuals) so as to considerably reduce any linkage disequilibrium which might have been present initially.
Eight Est-6 VS and 10 Est-6 VF homozygous lines (derived from the first intercross) were used in experiment $\mathrm{I}$, and 10 Est-6 $\mathrm{F}$ and 3 Est-6 VF homozygous lines (from the second intercross) in experiment II.

\section{(ii) Design of experiments}

In each experiment three laboratory populations were made up with three different genetic compositions $(p(\mathrm{VF})=0 \cdot 2 ; 0 \cdot 5 ; 0 \cdot 8)$. Each population was started with 600 three day old females fertilised by males of the same or of a different genotype so that the expected zygotic composition of the F1 Est-6 genotypes would agree with H.-W. expectations. The heterozygotes were the progeny of the reciprocal crosses between the two homozygous genotypes in equal proportions.

The population cages were set up with polyethylene cups containing $25 \mathrm{ml}$ of medium inserted in the base, as described by Beardmore et al. (1963). The food medium was prepared with $13 \mathrm{~g}$ of agar, $110 \mathrm{~g}$ of sucrose, $80 \mathrm{~g}$ of maize flour and $145 \mathrm{~g}$ of yeast per litre of water in the Experiment $\mathrm{I} ; 13 \mathrm{~g}$ of agar, $80 \mathrm{~g}$ of sucrose, $80 \mathrm{~g}$ of maize flour and $40 \mathrm{~g}$ of yeast in Experiment II. The mixture was cooked and boiled for 40 minutes, then cooled to $42^{\circ} \mathrm{C}$ and $15.6 \mathrm{ml} /$ litre of a solution of nipagin $(60 \mathrm{~g}$ in $340 \mathrm{ml}$ of 96 per cent ethanol) added to prevent bacterial and fungal growth. The population cages were kept at $24^{\circ} \mathrm{C}$ in order to allow the females to lay eggs in the cups. The cups were removed after 48 hours of oviposition and substituted with a second series of cups containing fresh medium, in order to analyse any possible difference in fecundity or viability with respect to the period of oviposition. To analyse the possible effect of temperature on the genetic composition of the $F 1$, cups from each population cage were put at two different temperatures $\left(17^{\circ} \mathrm{C}\right.$ and $\left.23^{\circ} \mathrm{C}\right)$ in experiment $\mathrm{I}$ and at three different temperatures $\left(17^{\circ} \mathrm{C}, 23^{\circ} \mathrm{C}\right.$ and $\left.30^{\circ} \mathrm{C}\right)$ in experiment II. Taking all possible combinations of the variables (genetic composition, temperature and period of oviposition) we had in all 12 blocks in experiment $I$ and 18 blocks in experiment $I$. In both the experiments five replicates were set up for each block. All the emerging $\mathrm{Fl}$ individuals were collected daily at the same time of day, sexed and stored at $-30^{\circ} \mathrm{C}$ until the electrophoretic assays were performed.

Since in Experiment II one more temperature $\left(30^{\circ} \mathrm{C}\right)$ was used than in Experiment $\mathrm{I}$, in order to render the daily technical work manageable, we reduced the productivity by reducing the quantities of yeast and sucrose in the medium. 


\section{(iii) Electrophoretic analysis}

In order to estimate genotypic frequencies about 50 flies were assayed from each replicate, except at $30^{\circ} \mathrm{C}$ in experiment II where the viability was significantly reduced so that 50 flies were sometimes not available. To avoid any possible bias due to differences in the time of development of different genotypes the flies were chosen so that each day of emergence was proportionally represented, and at random within each day of emergence. Electrophoresis and staining procedures were as previously reported (Costa and Beardmore, 1980).

\section{(iv) Statistical analysis}

For the analysis of the experimental data, we adopted discrete multivariate analyses using log linear models including main effects of each factor and all interactions (see Gokhale and Kullback, 1978). The test statistic used is $\mathrm{G}^{2}$.

To test for the presence of selection in general and for frequency dependent selection in particular we used statistical analyses based on the plots suggested by Bundgaard and Christiansen (unpublished manuscript). Let $\mathrm{Z} 1, \mathrm{Z} 2, \mathrm{Z} 3$ be the frequencies of the genotypes AA, Aa, aa at a diallelic locus, and let the fitnesses of $\mathrm{AA}$ and aa relative to $A a$ be $\mathrm{W} 1$ and $\mathrm{W} 3$.

Further let $\mathrm{R} 1=\mathrm{Z} 1 / \mathrm{Z} 2$ and $\mathrm{R} 2=\mathrm{Z} 3 / \mathrm{Z} 2$. Then $\mathrm{R} 1 \times \mathrm{R} 2=\mathrm{W} 1 \times \mathrm{W} 3 / 4$, and consequently $\log (\mathrm{R} 2)=\log (\mathrm{W} 1 \times \mathrm{W} 3 / 4)-\log (\mathrm{R} 1)$. Thus in the absence of frequency dependent selection a plot of $\log (\mathrm{R} 2)$ against $\log (\mathrm{R} 1)$ should be a straight line with slope $b=-1$ and intercept $a=$ $\log (\mathrm{W} 1 \times \mathrm{W} 3 / 4)$. If there is no selection then the intercept should be $\log (0 \cdot 25)$. Thus significant deviations of the data points from the straight line $Y=a-X$ should be evidence for the presence of frequency dependent selection. If there is no significant deviation from this line but the deviations from the line $Y=\log (0 \cdot 25)-X$ are significant this should demonstrate that frequency independent selection is operating.

\section{RESULTS}

In each experimental combination, five replicates were carried out. Three of the 30 combinations gave a value of $\mathrm{G}^{2}$ for heterogeneity between replicates for sex ratio which was significant at the 5 per cent level. The probability of this event or a more extreme one is $0 \cdot 127$. For the genotype ratios also three of the 30 combinations showed significant heterogeneity. In both cases therefore we considered it legitimate to pool the replicates and all the results described in this paper consider the pooled data.

Table 1 gives the results of the number of flies enclosed in the two experiments for the various combinations of experimental conditions. Table 2 gives the genotypic output observed in the two experiments.

The results of the analysis will be presented in two parts, the first dealing with the yields (i.e. the

Table 1 Number of flies eclosed in the two experiments for each combination of experimental conditions

\begin{tabular}{|c|c|c|c|c|c|c|c|c|}
\hline \multirow{2}{*}{$\begin{array}{l}\text { Period } \\
\text { of } \\
\text { oviposition }\end{array}$} & \multirow{2}{*}{$\begin{array}{l}\text { Temp } \\
\left({ }^{\circ} \mathrm{C}\right)\end{array}$} & \multirow{2}{*}{$\begin{array}{l}\text { Input } \\
\text { ratio } \\
p(\mathrm{VF})\end{array}$} & \multicolumn{3}{|c|}{ Yield Expt. I } & \multicolumn{3}{|c|}{ Yield Expt. II } \\
\hline & & & Male & Female & Total & Male & Female & Total \\
\hline \multirow[t]{9}{*}{$0-48$ hours } & \multirow[t]{3}{*}{$17^{\circ} \mathrm{C}$} & $0 \cdot 2$ & 535 & 556 & 1091 & 148 & 215 & 363 \\
\hline & & 0.5 & 633 & 647 & 1280 & 170 & 222 & 392 \\
\hline & & 0.8 & 459 & 501 & 960 & 135 & 226 & 361 \\
\hline & \multirow{3}{*}{$23^{\circ} \mathrm{C}$} & $0 \cdot 2$ & 475 & 540 & 1015 & 236 & 315 & 551 \\
\hline & & 0.5 & 597 & 724 & 1321 & 203 & 278 & 481 \\
\hline & & 0.8 & 673 & 784 & 1457 & 232 & 329 & 561 \\
\hline & \multirow[t]{3}{*}{$30^{\circ} \mathrm{C}$} & $0 \cdot 2$ & - & - & - & 62 & 118 & 180 \\
\hline & & 0.5 & - & - & - & 54 & 112 & 166 \\
\hline & & 0.8 & - & - & - & 35 & 97 & 132 \\
\hline \multirow[t]{9}{*}{ 48-96 hours } & \multirow[t]{3}{*}{$17^{\circ} \mathrm{C}$} & 0.2 & 553 & 556 & 1109 & 152 & 189 & 341 \\
\hline & & 0.5 & 436 & 485 & 921 & 158 & 211 & 369 \\
\hline & & 0.8 & 458 & 499 & 957 & 134 & 165 & 299 \\
\hline & \multirow[t]{3}{*}{$23^{\circ} \mathrm{C}$} & 0.2 & 580 & 679 & 1259 & 266 & 341 & 607 \\
\hline & & 0.5 & 574 & 612 & 1186 & 129 & 120 & 249 \\
\hline & & 0.8 & 490 & 526 & 1016 & 168 & 190 & 358 \\
\hline & \multirow[t]{3}{*}{$30^{\circ} \mathrm{C}$} & 0.2 & - & - & - & 44 & 84 & 128 \\
\hline & & 0.5 & - & - & - & 18 & 46 & 64 \\
\hline & & 0.8 & - & - & - & 22 & 43 & 65 \\
\hline
\end{tabular}


Table 2 Genotypic output observed in the two experiments for each combination of experimental conditions

\begin{tabular}{|c|c|c|c|c|c|c|c|c|}
\hline \multirow{2}{*}{$\begin{array}{l}\text { Period } \\
\text { of } \\
\text { oviposition }\end{array}$} & \multirow{2}{*}{$\begin{array}{l}\text { Temp. } \\
\left({ }^{\circ} \mathrm{C}\right)\end{array}$} & \multirow{2}{*}{$\begin{array}{l}\text { Input } \\
p(\mathrm{VF})\end{array}$} & \multicolumn{3}{|c|}{$\begin{array}{l}\text { Genotypic output } \\
\text { Experiment I }\end{array}$} & \multicolumn{3}{|c|}{$\begin{array}{l}\text { Genotypic output } \\
\text { Experiment II }\end{array}$} \\
\hline & & & VS/VS & $\mathrm{VS} / \mathrm{VF}$ & $\mathrm{VF} / \mathrm{VF}$ & $F / F$ & $\mathrm{~F} / \mathrm{VF}$ & $\mathrm{VF} / \mathrm{VF}$ \\
\hline \multirow[t]{7}{*}{$0-48$ hours } & \multirow[t]{3}{*}{$17^{\circ} \mathrm{C}$} & $0 \cdot 2$ & 164 & 77 & 11 & 155 & 129 & 10 \\
\hline & & 0.5 & 66 & 128 & 57 & 54 & 145 & 27 \\
\hline & & 0.8 & 10 & 112 & 130 & 9 & 161 & 48 \\
\hline & $23^{\circ} \mathrm{C}$ & 0.8 & 5 & 88 & 159 & 13 & 146 & 89 \\
\hline & \multirow[t]{3}{*}{$30^{\circ} \mathrm{C}$} & $0 \cdot 2$ & - & - & - & 129 & 48 & 0 \\
\hline & & 0.5 & - & - & - & 60 & 101 & 5 \\
\hline & & 0.8 & - & - & $\ldots$ & 20 & 82 & 28 \\
\hline \multirow[t]{5}{*}{$48-96$ hours } & \multirow[t]{2}{*}{$17^{\circ} \mathrm{C}$} & $0 \cdot 2$ & 132 & 108 & 12 & 171 & 52 & 1 \\
\hline & & 0.5 & 65 & 127 & 65 & 95 & 114 & 18 \\
\hline & \multirow[t]{3}{*}{$30^{\circ} \mathrm{C}$} & 0.2 & - & - & - & 81 & 41 & 1 \\
\hline & & 0.5 & - & - & - & 33 & 28 & 1 \\
\hline & & 0.8 & - & - & - & 12 & 47 & 6 \\
\hline
\end{tabular}

total number of flies emerging) for the various combinations of conditions, and the second dealing with the genotypic distributions of the samples. The analysis carried out was a factorial $\mathrm{G}^{2}$ analysis (see Gokhale and Kullback, 1978). The factors were the timing of oviposition, the temperature, and the sex (genotypes in the second part). In the first part, the input gene frequency was included as one of the factors. This was not possible however in the analysis of genotype frequencies; in the latter case the results of the three input gene frequencies had to be analysed separately.

\section{(i) Yield in Experiment I}

The simplest model which explains the data takes into consideration the difference in yield between sexes (sex ratio different from 1:1) and a three-way interaction between the other factors (goodness of fit $\left.\mathrm{G}^{2}[11]=11 \cdot 15\right)$. The sex ratio is biased in favour of females (see table 3). As for the other three

Table 3 Sex ratio in the two experiments. The results of Experiment II arc subdivided so that section lla concerns total yields at $17+23^{\circ} \mathrm{C}$, section $1 \mathrm{lb}$ yields at $30^{\circ} \mathrm{C}$. ${ }^{*} \mathrm{P}<$ $0 \cdot 001$. The same notation is used in the following tables

\begin{tabular}{|c|c|c|c|c|c|}
\hline Experiment & Males & Females & Total & $\begin{array}{l}\text { Male/ } \\
\text { female }\end{array}$ & $G^{2}\lfloor 1]$ \\
\hline I & 6463 & 7109 & 13572 & 0.91 & $30 \cdot 8^{*}$ \\
\hline Ila & 2131 & 2801 & 4932 & 0.76 & $91 \cdot 3^{*}$ \\
\hline IIb & 235 & 500 & 735 & 0.47 & $97.7^{*}$ \\
\hline
\end{tabular}

factors, more flies emerge from the eggs laid in the first 48 hours than in the subsequent 48 hours (table 4) and the yield is higher at $23^{\circ} \mathrm{C}$ than at $17^{\circ} \mathrm{C}$ (table 5). Also the yield is highest at $p(\mathrm{VF})=0.5$ (table 6).

Table 4 Number of flies emerged in the two experiments in the two periods of oviposition. 01 refers to individuals emerged from eggs laid in the first 48 hours; 02 to those emerged from eggs of the subsequent 48 hours. The same notation is used in the following tables

\begin{tabular}{lcrrrr}
\hline & \multicolumn{5}{c}{ Period of oviposition } \\
\cline { 2 - 6 } Experiment & 01 & 02 & Total & $01 / 02$ & $\mathrm{G}^{2}[1]$ \\
\hline I & 7124 & 6448 & 13572 & $1 \cdot 10$ & $33 \cdot 7^{*}$ \\
IIa & 2709 & 2223 & 4932 & $1 \cdot 22$ & $48 \cdot 0^{*}$ \\
IIb & 478 & 257 & 735 & $1 \cdot 86$ & $67 \cdot 5^{*}$ \\
\hline
\end{tabular}

$*=\mathrm{P}<0.001$

There is a very intense interaction between the input frequency and the pattern of oviposition (table 7). There is also a strong interaction between the temperature and the input gene frequencies (table 8): there is a progressive decrease of the yield at $17^{\circ} \mathrm{C}$ relatively to that at $23^{\circ} \mathrm{C}$ (T1/T2) with increasing frequencies of Est-6 VF.

\section{(ii) Yield in Experiment II}

Besides the fact that the genotypes in competition are different, this experiment has also an additional temperature $\left(30^{\circ} \mathrm{C}\right)$. At this temperature there are 
Table 5 Yields at the temperatures used in the two experiments. $\mathrm{T} 1=17^{\circ} \mathrm{C} ; \mathrm{T} 2=23^{\circ} \mathrm{C}$;

$\mathrm{T} 3=30^{\circ} \mathrm{C}$. The same notation is used in the following tables.

\begin{tabular}{lllllllll}
\hline & \multicolumn{3}{c}{ Temperature } & & & & & \\
Expt. & T1 & T2 & T3 & Total & T1/T2 & T3/T2 & $\mathrm{G}^{2}$ & d.f. \\
\hline I & 6318 & 7254 & - & 13572 & $0 \cdot 87$ & - & $64 \cdot 6^{*}$ & 1 \\
II & 2125 & 2807 & 735 & 5667 & $0 \cdot 76$ & $0 \cdot 26$ & $1336 \cdot 3^{*}$ & 2 \\
\hline
\end{tabular}

Table 6 Yields for the input frequencies of the Est-6 VF allele in the two experiments

\begin{tabular}{|c|c|c|c|c|c|c|c|}
\hline \multirow[b]{2}{*}{ Expt. } & \multicolumn{3}{|c|}{$p(\mathrm{VF})=$ input frequency } & \multirow[b]{2}{*}{ Total } & \multirow[b]{2}{*}{$0 \cdot 2 / 0 \cdot 5$} & \multirow[b]{2}{*}{$0.8 / 0.5$} & \multirow[b]{2}{*}{$\mathrm{G}^{2}[2]$} \\
\hline & 0.2 & 0.5 & $0 \cdot 8$ & & & & \\
\hline I & 4474 & 4708 & 4390 & 13572 & 0.95 & 0.93 & $12 \cdot 0^{*}$ \\
\hline IIa & 1862 & 1491 & 1579 & 4932 & $1 \cdot 25$ & 1.06 & $45 \cdot 0^{*}$ \\
\hline I Ib & 308 & 230 & 197 & 735 & $1 \cdot 34$ & 0.86 & $26 \cdot 0^{*}$ \\
\hline
\end{tabular}

Table 7 Interaction between the influence of input frequency and the period of oviposition on the yield

\begin{tabular}{|c|c|c|c|c|c|c|}
\hline \multirow[b]{2}{*}{ Expt. } & \multirow{2}{*}{$\begin{array}{l}\text { Input } \\
p(\mathrm{VF})\end{array}$} & \multicolumn{2}{|c|}{ Period of oviposition } & \multirow[b]{2}{*}{ Total } & \multirow[b]{2}{*}{$01 / 02$} & \multirow[b]{2}{*}{$\mathrm{G}^{2}[2]$} \\
\hline & & 01 & 02 & & & \\
\hline \multirow[t]{3}{*}{ I } & 0.2 & 2106 & 2368 & 4474 & 0.89 & \\
\hline & 0.5 & 2601 & 2107 & 4708 & $1 \cdot 23$ & $78.7^{*}$ \\
\hline & 0.8 & 2417 & 1973 & 4390 & $1 \cdot 23$ & \\
\hline \multirow[t]{3}{*}{ IIa } & $0 \cdot 2$ & 914 & 948 & 1862 & 0.96 & \\
\hline & 0.5 & 873 & 618 & 1491 & $1 \cdot 41$ & $41 \cdot 2^{*}$ \\
\hline & 0.8 & 922 & 657 & 1579 & $1 \cdot 40$ & \\
\hline \multirow[t]{3}{*}{ IIb } & 0.2 & 180 & 128 & 308 & $1 \cdot 41$ & \\
\hline & 0.5 & 166 & 64 & 230 & $2 \cdot 59$ & $11 \cdot 4^{*}$ \\
\hline & 0.8 & 132 & 65 & 197 & 2.03 & \\
\hline
\end{tabular}

Table 8 Interaction between the influences of temperature and input gene frequency on the yield in the two experiments

\begin{tabular}{|c|c|c|c|c|c|c|c|c|}
\hline \multirow[b]{2}{*}{ Expt. } & \multirow{2}{*}{$\begin{array}{l}\text { Input } \\
p(\mathrm{VF})\end{array}$} & \multicolumn{3}{|c|}{ Temperature } & \multirow[b]{2}{*}{ Total } & \multirow[b]{2}{*}{$\mathrm{T} 1 / \mathrm{T} 2$} & \multirow[b]{2}{*}{$\mathrm{T} 2 / \mathrm{T} 3$} & \multirow[b]{2}{*}{$\mathrm{G}^{2}[2]$} \\
\hline & & $\mathrm{T} 1$ & $\mathrm{~T} 2$ & T3 & & & & \\
\hline \multirow[t]{3}{*}{ I } & 0.2 & 2200 & 2274 & - & 4474 & 0.97 & $\ldots$ & \\
\hline & 0.5 & 2201 & 2507 & - & 4708 & 0.88 & - & $27 \cdot 0^{*}$ \\
\hline & 0.8 & 1917 & 2473 & - & 4390 & 0.78 & - & \\
\hline \multirow[t]{3}{*}{ II } & 0.2 & 704 & 1158 & 308 & 2170 & 0.61 & $0 \cdot 27$ & \\
\hline & 0.5 & 761 & 730 & 230 & 1721 & 1.04 & $0 \cdot 32$ & $60 \cdot 5^{*}$ \\
\hline & 0.8 & 660 & 919 & 197 & 1776 & 0.72 & $0 \cdot 21$ & \\
\hline
\end{tabular}

$*=\mathrm{P}<0.001$

drastic selection effects (see table 5), and in the analysis we have tended to keep the results at $30^{\circ} \mathrm{C}$ separate. Thus while the model which considers sex ratio and the three-way interaction among oviposition pattern, temperature and input gene frequencies fits the data satisfactorily $\left(G^{2}[11]=\right.$ $17 \cdot 1$ ), if we include the results for $30^{\circ} \mathrm{C}$, this is no longer true; when these data are included, there is also a strong interaction between the sex ratio and the temperature. In fact males are strongly selected against at the highest temperature (table 3 ). Interaction between the temperature and the oviposition pattern is such that selection at $30^{\circ} \mathrm{C}$ is particularly strong in the second oviposition period (table 4). When only $17^{\circ} \mathrm{C}$ and $23^{\circ} \mathrm{C}$ are considered, the results for sex ratio, oviposition 
Table 9 Total output genotypes for the input $p$ (VF) frequencies in Experiment I. Genotypic and allelic fitnesses are relative to the heterozygote and the Est-VF allele respectively

\begin{tabular}{|c|c|c|c|c|c|c|c|c|}
\hline \multirow{2}{*}{$\begin{array}{l}\text { Expt. I } \\
p(\mathrm{VF})\end{array}$} & \multicolumn{3}{|c|}{$\begin{array}{c}\text { Output } \\
\text { genotypes }\end{array}$} & \multicolumn{2}{|c|}{ Fitness } & \multicolumn{2}{|c|}{$\begin{array}{l}\text { Output } \\
\text { alleles }\end{array}$} & \multirow{2}{*}{$\begin{array}{l}\text { Fitness } \\
\text { VS }\end{array}$} \\
\hline & $\mathrm{VS} / \mathrm{VF}$ & $\mathrm{VS} / \mathrm{VF}$ & $\mathrm{VF} / \mathrm{VF}$ & VS/VS & $\mathrm{VF} / \mathrm{VF}$ & VS & VF & \\
\hline $0 \cdot 2$ & 578 & 392 & 39 & 0.74 & 0.80 & 1548 & 470 & 0.82 \\
\hline 0.5 & 239 & 519 & 255 & 0.92 & 0.98 & 997 & 1029 & 0.97 \\
\hline 0.8 & 36 & 392 & 576 & 0.7 .3 & 0.73 & 464 & 1544 & $1 \cdot 20$ \\
\hline
\end{tabular}

pattern and temperature are qualitatively the same as in Expt. 1 (tables 3-5). The effect of input gene frequency is however different. The yield (pooling $17^{\circ} \mathrm{C}$ and $23^{\circ} \mathrm{C}$ ) is minimum at $p(\mathrm{VF})=0.5$ (table $6)$. While in general the yield is higher at $23^{\circ} \mathrm{C}$ relative to $17^{\circ} \mathrm{C}$ the only exception is when $p(\mathrm{VF})=$ 0.5 where the yields are effectively the same at $17^{\circ} \mathrm{C}$ and $23^{\circ} \mathrm{C}$ (table 8 ). Excluding $30^{\circ} \mathrm{C}$, the interaction between oviposition pattern and input gene frequency is as in Expt. I.

Even though most of the results of Expt. II at $17^{\circ} \mathrm{C}$ and $23^{\circ} \mathrm{C}$ are qualitatively the same as in Expt. I, there are nevertheless significant quantitative differences in sex ratio, oviposition pattern and temperature effects. All these effects are more pronounced in Expt. II. It must be kept in mind however that the media used in the two experiments are slightly different.

\section{(iii) Genotypic and allelic output in Expt. I}

Since none of the interactions between factors is significant, table 9 shows the totals for each input gene frequency over all the other factors. At all input gene frequencies, there is heterozygote advantage. We also used the statistical test of significance described earlier for the presence of frequency dependent and frequency independent selection. Using the 12 points calculated from the observed genotypic outputs of table 2 , we did not find any evidence for frequency dependent selection $(F[1,10]=1.14 ; \quad P>0.25)$ while there is evidence that frequency independent selection is operating $(\mathrm{F}[1,11]=10.18 ; \mathrm{P}<0.01$, table 10$)$.

\section{(iv) Genotypic and allelic output in Expt. II}

Once again, from the 17 usable points of table 2, we find that while there is no evidence for frequency dependent selection $(F[1,15]=0.13 ; \mathrm{P}>$ $0 \cdot 50)$ there is strong evidence for frequency independent selection $(\mathrm{F}[1,16]=77 \cdot 19 ; \mathrm{P} \ll 0.001$, table 10).
Table 10 Analysis of variance for testing for frequencyindependent and frequency dependent selection in the two experiments

\begin{tabular}{|c|c|c|c|c|}
\hline $\begin{array}{l}\text { EXPERIMENT I } \\
\text { Hypothesis }\end{array}$ & S.S. & d.f. & $\mathrm{F}$ & $\mathrm{P}$ \\
\hline$b=-1 ; a=\log (0 \cdot 25)$ & $4 \cdot 73$ & 12 & & \\
\hline (Difference) & $2 \cdot 27$ & 1 & $10 \cdot 18$ & $<0.01$ \\
\hline$b=-1 ; a$ estimated & $2 \cdot 46$ & 11 & & \\
\hline (Difference) & 0.25 & 1 & $1 \cdot 14$ & n.s. \\
\hline$a, b$ estimated & $2 \cdot 21$ & 10 & & \\
\hline $\begin{array}{l}\text { I:XPERIMENT II } \\
\text { Hypothesis }\end{array}$ & S.S. & d.f. & $\mathrm{F}$ & $\mathrm{P}$ \\
\hline$b=-1 ; a=\log (0 \cdot 25)$ & $43 \cdot 19$ & 17 & & \\
\hline (Difference) & $35 \cdot 77$ & 1 & $77 \cdot 19$ & $\ll 0.001$ \\
\hline$b=-1 ; a$ estimated & $7 \cdot 42$ & 16 & & \\
\hline (Difference) & 0.07 & 1 & $0 \cdot 13$ & n.s. \\
\hline$a, b$ estimated & $7 \cdot 35$ & 15 & & \\
\hline
\end{tabular}

Tables 11 and 12 show the genotypic and allelic outputs summed respectively over sex and oviposition or sex and temperature in order to study the effects of the factors on the fitnesses. There is almost always strong selection against the Est-6 $\mathrm{VF}$ allele, the only exceptions being for $p(\mathrm{VF})=0 \cdot 2$ both at $23^{\circ} \mathrm{C}$ and the first oviposition period (01). There is also a highly significant difference between the selective effects in the two oviposition periods. While in the first 48 hours the heterozygote is the fittest genotype (except at $30^{\circ} \mathrm{C}$ ), among the eggs laid in the second period there is directional selection.

\section{DISCUSSION}

No comparison is possible between the two experiments as far as total productivity is concerned due to the slight differences in the media (see Materials and Methods). Nevertheless the model which considers sex ratio, oviposition pattern and temperature fits the data qualitatively in the same way in the two experiments when $17^{\circ} \mathrm{C}$ and $23^{\circ} \mathrm{C}$ are 
considered. This could indicate that the diversity in larval density between the two experiments did not greatly affect the qualitative pattern of interactions between the considered factors.

The variation in total yield with input gene frequencies is different in the two experiments (table 6) and this may be due to intrinsic reproductive and perhaps other features of the homozygous lines used in the experiments. Preliminary estimates of fecundity of the different genotypes, measured for single fertilised females, showed the existence of differences even if we cannot extrapolate them to our experimental conditions which differed for example with respect to crowding.

As for temperature effects, in addition to the fact that the highest yield was always observed at $23^{\circ} \mathrm{C}$, the highest temperature considered $\left(30^{\circ} \mathrm{C}\right)$ produced drastic effects and in addition also affected males much more than females. There is a strong interaction between input gene frequency and the pattern of oviposition such that the yield in the first period relative to that in the second is considerable lower at $p(\mathrm{VF})=0 \cdot 2$. In addition this ratio is much higher at $30^{\circ} \mathrm{C}$ with respect to $17^{\circ} \mathrm{C}$ and $23^{\circ} \mathrm{C}$ (table 7 ). It seems worth considering the hypothesis that this interaction is due to a difference in the pattern of oviposition among genotypes. Previous results (Gilbert and Richmond, 1982) have suggested that male Est-6 promotes ejaculate transfer, sperm storage and use in females. A quantitative study of sperm use during the first 50 hours after mating by using Est-6 null and active stocks of Drosophila melanogaster (Gilbert et al., 1981) demonstrated that the rate of sperm release is related to the level of Esterase- 6 activity suggesting the involvement of this enzyme, present in the seminal fluid, in sperm motility. Moreover 3 or 4 days after mating few sperms are present in the receptacle and at this time also the fertilisation rate begins to drop together with the number of eggs (David, 1963; Pyle and Gromko, 1978). As for sperm release it has been hypothesized that Esterase- 6 plays a primary role in determining its initial rapid rate (Gilbert et al., 1981) which declines 2 or 3 days after mating. Since functional differences have been detected among Est-6 allozymes, in particular between rare and frequent variants (Costa et al., 1983), we suggest that the differences in yield observed in our experiments in the two periods of oviposition considered and for different input frequencies are mainly due to the differences in the catalytic properties of the allozymes in the physiological process of sperm use.

In Experiment I no interaction was observed between the factors considered. The heterozygote is always the fittest genotype. It is interesting to note that the two alleles VF and VS which are both rare in nature have very similar fitnesses when competing with each other (table 9).

The genotypic and allelic output in Exp. II, where the Est-6 polymorphism included the Est-6 $F$ and Est-6 VF alleles, indicates the presence of strong selection (tables 11 and 12). In this experiment while heterozygote advantage is again evident at $17^{\circ} \mathrm{C}$ and $23^{\circ} \mathrm{C}$ there is a clear shift towards directional selection at $30^{\circ} \mathrm{C}$. Contrary to Exp. I, in Exp. II the Est-6 VF allele is in general strongly selected against with only one exception. The strong selection against Est-6 VF suggested by these results is in agreement with the fact that in nature it is very rare while Est-6 F is a common allele in the populations from which our lines are derived (Danieli and Costa, 1977).

Particularly interesting in Exp. II seems the interaction between the mode of selection and the oviposition period at $17^{\circ} \mathrm{C}$ and $23^{\circ} \mathrm{C}$, when a shift from heterosis in the first oviposition period to

Table 11 Total genotypic and allelic output for the input Est-6 VF frequencies and temperatures in Experiment II. Fitnesses are as in table 9

\begin{tabular}{|c|c|c|c|c|c|c|c|c|c|}
\hline \multirow{2}{*}{$\begin{array}{l}\text { Expt. } \\
\text { II } \\
\text { Temp. }\end{array}$} & \multirow{2}{*}{$\begin{array}{l}\text { Input } \\
p(\mathrm{VF})\end{array}$} & \multicolumn{3}{|c|}{$\begin{array}{c}\text { Output } \\
\text { genotypes }\end{array}$} & \multicolumn{2}{|c|}{ Fitness } & \multicolumn{2}{|c|}{$\begin{array}{l}\text { Output } \\
\text { alleles }\end{array}$} & \multirow{2}{*}{$\begin{array}{l}\text { Fitness } \\
\text { F }\end{array}$} \\
\hline & & $\mathrm{F} / \mathrm{F}$ & $\mathrm{F} / \mathrm{VF}$ & $\mathrm{VF} / \mathrm{VF}$ & $\mathrm{F} / \mathrm{F}$ & $\mathrm{VF} / \mathrm{VF}$ & $\mathrm{F}$ & VF & \\
\hline \multirow[t]{3}{*}{$17^{\circ} \mathrm{C}$} & $0 \cdot 2$ & 326 & 181 & 11 & $0 \cdot 90$ & 0.49 & 833 & 203 & 1.03 \\
\hline & 0.5 & 149 & 259 & 45 & $1 \cdot 15$ & 0.35 & 557 & 349 & $1 \cdot 60$ \\
\hline & 0.8 & 21 & 256 & 119 & 0.67 & $0 \cdot 23$ & 298 & 494 & $2 \cdot 41$ \\
\hline \multirow[t]{3}{*}{$23^{\circ} \mathrm{C}$} & $0 \cdot 2$ & 257 & 261 & 3 & 0.49 & 0.09 & 775 & 267 & $0 \cdot 73$ \\
\hline & 0.5 & 113 & 273 & 45 & 0.83 & 0.33 & 499 & 363 & $1 \cdot 37$ \\
\hline & $0 \cdot 8$ & 29 & 239 & 208 & 0.97 & 0.44 & 297 & 655 & $1 \cdot 81$ \\
\hline \multirow[t]{3}{*}{$30^{\circ} \mathrm{C}$} & 0.2 & 210 & 89 & 2 & $1 \cdot 18$ & $0 \cdot 18$ & 509 & 93 & $1 \cdot 37$ \\
\hline & 0.5 & 93 & 129 & 6 & 1.44 & 0.09 & 315 & 141 & $2 \cdot 23$ \\
\hline & 0.8 & 32 & 129 & 34 & $1 \cdot 98$ & $0 \cdot 13$ & 193 & 197 & 3.92 \\
\hline
\end{tabular}


Table 12 Total genotypic and allelic outputs for the input Est-6 VF frequencies and oviposition periods in Experiment II. Fitnesses are as in Table 9

\begin{tabular}{|c|c|c|c|c|c|c|c|c|c|c|}
\hline \multirow{2}{*}{$\begin{array}{l}\text { Expt. } \\
\text { II }\end{array}$} & \multirow{2}{*}{$\begin{array}{l}\text { Oviposition } \\
\text { period }\end{array}$} & \multirow{2}{*}{$\begin{array}{l}\text { Input } \\
p(\text { VF })\end{array}$} & \multicolumn{3}{|c|}{$\begin{array}{r}\text { Output } \\
\text { genotypes }\end{array}$} & \multicolumn{2}{|c|}{ Fitness } & \multicolumn{2}{|c|}{ Alleles } & \multirow{2}{*}{$\begin{array}{l}\text { Fitness } \\
\text { F }\end{array}$} \\
\hline & & & $\mathrm{F} / \mathrm{F}$ & $\mathrm{F} / \mathrm{VF}$ & $\mathrm{VF} / \mathrm{VF}$ & $\mathrm{F} / \mathrm{F}$ & $\mathrm{VF} / \mathrm{VF}$ & $\mathrm{F}$ & $\mathrm{VF}$ & \\
\hline \multirow[t]{6}{*}{$\mathrm{Ha}$} & \multirow[t]{3}{*}{01} & 0.2 & 261 & 296 & 11 & 0.44 & $0 \cdot 30$ & 818 & 318 & $0 \cdot 64$ \\
\hline & & 0.5 & 99 & 313 & 46 & 0.63 & $0 \cdot 29$ & 511 & 405 & $1 \cdot 26$ \\
\hline & & 0.8 & 22 & 307 & 137 & 0.57 & $0 \cdot 21$ & 351 & 581 & $2 \cdot 42$ \\
\hline & \multirow[t]{3}{*}{02} & 0.2 & 322 & 146 & 3 & $1 \cdot 10$ & $0 \cdot 16$ & 790 & 152 & $1 \cdot 30$ \\
\hline & & 0.5 & 163 & 219 & 44 & 1.49 & 0.40 & 545 & 307 & 1.78 \\
\hline & & 0.8 & 28 & 188 & 190 & $1 \cdot 19$ & 0.51 & 244 & 568 & $1 \cdot 72$ \\
\hline \multirow[t]{6}{*}{ Ilb } & \multirow[t]{3}{*}{01} & 0.2 & 129 & 48 & 1 & $1 \cdot 34$ & $0 \cdot 17$ & 306 & 50 & 1.53 \\
\hline & & 0.5 & 60 & 101 & 5 & $1 \cdot 19$ & $0 \cdot 10$ & 221 & 111 & $1 \cdot 99$ \\
\hline & & 0.8 & 20 & 82 & 28 & 1.95 & 0.17 & 122 & 138 & 3.54 \\
\hline & \multirow[t]{3}{*}{02} & $0 \cdot 2$ & 81 & 41 & 1 & 0.99 & $0 \cdot 20$ & 203 & 43 & $1 \cdot 18$ \\
\hline & & 0.5 & 33 & 28 & 1 & $2 \cdot 36$ & 0.07 & 94 & 30 & $3 \cdot 13$ \\
\hline & & 0.8 & 12 & 47 & 6 & $2 \cdot 04$ & 0.06 & 71 & 59 & $4 \cdot 81$ \\
\hline
\end{tabular}

directional selection against Est-6 VF in the second one was observed (table 12). However this may not be due to selective mechanisms but to the relative differences that might exist in the timing of oviposition among fertilised females depending on the male Est- 6 genotype as mentioned above.

The overall picture apparently suggests that selection patterns are similar for the two experiments in spite of possible differences in the genetic background among the lines used in the two experiments. This could mean that the Est-6 locus is really involved in determining detectable fitness component(s). Further these results are similar to those obtained by several authors working with lines with possible dissimilarities in their genetic backgrounds (MacIntyre and Wright, 1966; Kojima and Yarbrough, 1967 ; Kojima and Huang, 1972; Birley and Beardmore, 1977; Minawa and Birley, 1975; Morgan, 1976; Oakeshott, 1979; Abedin et al., 1980; Costa and Beardmore, 1980). While one can see in general selection against the Est-6 VF allele in the results of tables 11 and 12, there are two exceptions, both for $p(V F)=0 \cdot 2$, one at a temperature of $23^{\circ} \mathrm{C}$ and the other for the first 48 hours of oviposition. From the analysis of the yield these are the optimal growth conditions. In other words the allele Est-6 VF is at a disadvantage when conditions are suboptimal, and further it is possible that it shows selection when rare enough.

On the other hand apparent selective responses regarding a locus under study may be due to the fact that other linked loci are the true targets of selection. The lines used in this study were isolated by randomising their genomes and reducing the possibility of the persistence of genetic variation at closely linked loci; nevertheless we cannot exclude the possible effects of other loci on the results obtained. We have performed other onegeneration experiments to test the actual role of the Est-6 locus in determining fitness by using highly inbred lines obtained with a procedure reported elsewhere (Costa et al., 1985). There too we obtained results in agreement with the hypothesis that attributes an adaptive role to the Est-6 polymorphism. Nevertheless the dynamics of this polymorphism studied over several generations in experimental populations set up with our highly inbred lines suggests that part of the selection associated with the locus under more or less pronounced outbred conditions has been eliminated (Costa et al., in preparation). It seems likely then that there is a good deal of interaction of the Est- 6 locus with other systems possibly in linkage disequilibrium in the wild or in laboratory populations derived from outbred lines even though studies devoted to discover linkage disequilibrium in wild populations in the chromosomal arm carrying the Est-6 locus in natural populations of Drosophila melanogaster have not been successful (see references in Costa et al., 1985).

It has by now become evident that the Est- 6 polymorphism has an adaptive significance based either on its already demonstrated involvement in the reproductive process (Gilbert and Richmond, 1982 ) or on its role in the metabolism of esters (Zera et al., 1983; Costa et al., 1985). The results reported here together with the other findings for outbred and inbred populations cited above, suggest however that the Est-6 locus is not only involved in selective processes per se but also because of its interactions with other loci. How this occurs remains to be studied, but considering 
the overall pattern of results produced by studies on the Est-6 locus it is suggested that this polymorphism in the wild is maintained by complex and interacting modes of selection.

Acknowledgements This work was supported by a grant from the Italian Ministry of Public Education.

\section{REFERENCES}

ABEDIN, K., MCNAMARA, S., OSTERBUR, D. AND STEINER, W. W. M. 1980. Studies on the effect of temperature on fitness and the fecundity at the Esterase-6 locus in D. melanogaster. Drosoph. Inf. Serv., 55, 10-11.

ANDERSON, P. R. AND OAKESHOTT, J. G. 1984. Parallel geographical pattern of allozyme variation in two sibling Drosophila species. Nature, 308, 729-731.

BEARDMORE, J. A., VAN DELDEN, W. AND ALKEMA, L. 1963. A population cage for incubator use. Drosoph. Inf. Serv., $37,137-138$.

BIRLEY, A. J. AND BEARDMORE, J. A. 1977. Genetical composition, temperature, density and selection in an enzyme polymorphism. Heredity, 39, 133-144.

CLEGG, M. T., KIDWELL, J. F. AND DANIEL, N. J. 1976. Dynamics of correlated genetic system. I. Selection in the region of the Glued locus in Drosophila melanogaster. Genetics, 83, 793-810.

CLEGG, M. T., KIDWELL, J. F. AND KIDWELL, M. G. 1978. Dynamics of correlated systems. III. Behavior of chromosome segments under lethal selection. Genetica 48, 95-106.

COSTA, R. AND BEARDMORE, J. A. 1980. Selection in a polymorphism with a rare allele. Genetica 54, 167-172.

COSTA, R., NIGRO, L. AND DANIELI, G. A. 1982. Evolutionary significance of an enzymatic polymorphism. In "Evolution and the Genetics of populations", S. D. Jayakar and L. Zonta eds., Suppl. Atti Ass Genet. It., 29, 103-120.

COSTA, R., NIGRO, L. AND DANIELI, G. A. 1983. Esterase-6 allozymes: biochemical studies of two common and one rare variant in Drosophila melanogaster. Biochem. Genet., 21, 191-197.

COSTA, R., NIGRO, L., CAMBISSA, V., JAYAKAR, S. D., ZONTA, L. AND BEARDMORE, J. A. 1985. Selection in highly inbred populations of Drosophila melanogaster polymorphic at a single locus. Heredity, (in press).

DANFORD, N. D. AND BEARDMORE, J. A. 1979. Biochemical properties of Esterase-6 in Drosophila melanogaster. Biochem. Genet., 17, 1-22.

DANFORD, N. D. AND BEARDMORE, J. A. 1980. Selection at the esterase- 6 locus in Drosophila melanogaster by added enzyme substrates in the culture medium. Genetica, 50 , 171-178.

DANIELI, G. A. AND COSTA, R. 1977. Transient equilibrium at the Est-6 locus in wild population of Drosophila melanogaster, Genetica, 47, 37-41.

DAVID, J. 1963. Influence de la fécondation de la femelle sur le nombre et la taille des oeufs pondues étudié chez Drosophila malanogaster Meig. J. Insect Physiol., 9, 13-24.
DOLAN, R. AND ROBERTSON, A. 1975. The effect of conditioning the food medium in Drosophila in relation to frequency dependent selection. Heredity, 35, 311-316.

GILBERT, D. G. 1981. Ejaculates esterase-6 and initial sperm use by female Drosophila melanogaster. J. Insect. Physiol., 27, 641-650.

GILBERT, D. G., RICHMOND, R. C. AND SHEEHAN, K. B. $1981 a$. Studies of esterase-6 in Drosophila melanogaster. V. Progeny production and sperm use in females inseminated by males having active or null alleles. Evolution, 35, 21-37.

GILBERT, D. G. AND RICHMOND, R. C. 1982. Studies of esterase6 in Drosophila melanogaster. XII. Evidence for temperature selection of Est-6 and Adh alleles. Genetica, 58, 109-119.

GOKHALE, D. V. AND KULLBACK, S. 1978. The information in contingency tables. M. Dekker Inc., New York.

KOJIMA, K. AND YARBROUGH, K. M. 1967. Frequency-dependent selection at the Esterase-6 locus in Drosophila melanogaster. Proc. Natl. Acad. Sci. USA, 57, 645-649.

KOJIMA, K. AND HUANG, S. L. 1972. Effects of population density on the frequency-dependent selection in the Esterase-6 locus in Drosophila melanogaster. Evolution, 26, 313-321.

MACINTYRE, R. J. AND WRIGHT, T. R. F. 1966. Responses of Esterase-6 alleles of Drosophila melanogaster to selection in experimental populations. Genetics, 53, 371-375.

MANE, S. D., TEPPER, C. S. AND RICHMOND, R. C. 1983. Studies of Esterase-6 in Drosophila melanogaster. XIII. Purification and characterization of the two major isozymes. Biochem. Genet., 21, 1019-1040.

MINAWA, A. AND BIRLEY, A. J. 1975. Genetical and environmental diversity in Drosophila melanogaster. Nature, 255, 702-704.

MORGAN, P. 1976. Frequency dependent selection at two enzyme loci in Drosophila melanogaster. Nature, 263, 765766.

OAKESHOTT, J. G. 1979. Selection affecting enzyme polymorphism in laboratory populations of Drosophila melanogaster. Oecologia, 43, 341-354.

OAKESHOTT, J. G., CHAMBERS, C. K., GIBSON, J. B. AND WILCOCKS, D. A. 1981. Latitudinal relationship of Esterase-6 and Phosphoblucomutase gene frequencies in Drosophila melanogaster. Heredity, 47, 385-396.

PYLE, D. W. AND GROMKO, M. H. 1978. Repeated mating by female Drosophila melanogaster: the adaptive importance. Experientia, 34, 449-450.

RICHMOND, R. C., GILBERT, D. G., SHEEHAN, K. B., GROMKO, M. H. AND BUTTERWORTH. F. M. 1980. Esterase-6 and reproduction in Drosophila melanogaster. Science, 207, 1483-1485.

RICHMOND, R. C. AND SENIOR, A. 1981. Studies of Esterase-6 in Drosophila melanogaster. IX. Kinetics of transfer to females, decay in females and male recovery. $J$. Insect. Physiol., 27, 849-853.

WRIGHT, T. R. F. 1963. The genetics of an esterase in Drosophila melanogaster. Genetics, 48, 787-801.

ZERA, A. J., KOEHN, R. K. AND HALL, J. G. 1983. Comprehensive Insect Physiology, Biochemistry and Pharmacology, Vol. 10 Eds. Kerkut G. A. and Gilbert L. I., Pergamon, New York. 